\title{
Effect of the Mineralogical Composition of Limestone on the Properties of Mortars
}

\author{
Carla Macie1, Arão Manhique², Rodrigues Manjate1, Carvalho Madivate ${ }^{2 *}$ \\ ${ }^{1}$ Laboratório de Engenharia de Moçambique, Maputo, Moçambique \\ ${ }^{2}$ Departamento de Química da Universidade Eduardo Mondlane, Maputo, Mozambique \\ Email: *cmadivate@gmail.com,cmadivate@uem.mz
}

Received 20 April 2016; accepted 23 May 2016; published 26 May 2016

Copyright (C) 2016 by authors and Scientific Research Publishing Inc.

This work is licensed under the Creative Commons Attribution International License (CC BY). http://creativecommons.org/licenses/by/4.0/

(c) (i) Open Access

\begin{abstract}
Limestone has been used as a partial substitute for cement, due to its beneficial effect on mechanical properties of mortars and concretes. In the present research, we studied the effect of the mineralogical composition in mortars produced from limestone samples collected in different areas of Mozambique, using two cement types (Portland cement 32.5N and 42.5N). Additions of 10 to $25 \%$ limestone gave, in general and for the $32.5 \mathrm{~N}$ cement, good results of the compressive strength for all limestone samples, while for the $42.5 \mathrm{~N}$ only the Massinga samples performed well. Effect of the limestone additions on the flexural strength showed a beneficial effect for all samples and at all compositions studied, when using the $42.5 \mathrm{~N}$ cement, while for the $32.5 \mathrm{~N}$ cement only additions of $10 \%$ limestone gave values of the flexural strength higher than the reference material, with the exception of the Magude samples.
\end{abstract}

\section{Keywords}

Mortars, Concrete, Limestone, Filler

\section{Introduction}

The use of limestone as partial replacement for cement and fine aggregates in concretes and mortars is receiving increasing attention in recent years. Its use contributes for cost savings through replacement of cement or sand by a product of the limestone extraction industry, and for reduction of the environmental pollution through elimination of dust disposal and reduction of $\mathrm{CO}_{2}$ emissions associated with cement production [1]-[4].

Limestone fines have been used as the only substitute or in combination with other materials with a potential pozzolanic activity like blast-furnace slags and ashes from agriculture by-products [5]-[8]. Ashes become a rele-

\footnotetext{
${ }^{*}$ Corresponding author.
}

How to cite this paper: Macie, C., Manhique, A., Manjate, R. and Madivate, C. (2016) Effect of the Mineralogical Composition of Limestone on the Properties of Mortars. Journal of Materials Science and Chemical Engineering, 4, 16-24.

http://dx.doi.org/10.4236/msce.2016.45003 
vant pozzolanic material when processed under conditions where a significant amount of amorphous silica is developed [4]. These materials present a better reactivity with cement components and develop normally a better strength than the effect observed with limestone additions, giving values of the compressive strength more similar to the values obtained for the conventional material, even for higher substitution of cement [9] [10].

It has a physical effect (filler effect) and also a chemical contribution in the improvement of the properties of mortars and concretes. It reacts with tri-calcium aluminate in cement to form calcium carbo-aluminate; promotes early hydration of cement and interacts with aluminate formed during hydration, leading to a decrease of porosity and increase of strength of concrete, within certain amounts of limestone [1] [10] [11].

Menadi et al. [2] worked with 4 different cements to prepare samples from the conventional material (without replacement of sand by limestone) and samples where sand was replaced by $15 \%$ limestone and registered a decrease in compressive strength for all cement types. Menéndez et al. [5] reported an increase of the compressive strength at earlier curing ages (1, 7 and 14 days) and comparable values by 28 days curing age, in compositions where $10 \%$ Portland cement had been replaced by limestone. When the amount of cement replaced was increased to $20 \%$ compressive strength reduced at all curing ages. Limestone showed, at same amounts and at curing ages of 1 to 28 days, a better effect than the blast-furnace slag with a high amount of $\mathrm{SiO}_{2}$, normally present in amorphous form, while blast-furnace slag seemed to develop a better strength at higher curing ages (90 days).

Meddah et al. [1] worked with contents of limestone varying from 15 to $45 \%$ and registered a decrease in the entire interval, even at the different water to cement ratios they worked on. Lollini et al. [12] showed a significant increase of properties of concrete, but their results shall be discussed carefully since they used a synthetic binder that might have a significant contribution in the improved properties, contrary to the work where no synthetic binder had been used.

Bizzozero and Scrivener [11] studied the effect of the replacement of $20 \%$ cement by $20 \%$ limestone, on one side, and $20 \%$ quartz, on the other side, in low and high calcium sulphate environments. Mortars with limestone show, in low calcium sulphate environments, results of the compressive strength are more similar to the conventional mortar (without substitution) when compared to mortars with quartz, at different curing ages. In high calcium sulphate environments higher results of the compressive strength are obtained for conventional mortar and mortars with substitution by quartz and limestone, but results for both substituents are lower than the ones obtained with conventional mortar, with quartz and limestone mortars producing comparable results.

In a long term, limestone additions to materials used in high sulphate environments lead to formation of gypsum by reaction with the sulphate and the resulting decrease in compressive strength [3]. The role of sulphate is not consensually described. Ghrici et al. [13] report a beneficial effect of limestone on the improvement of sulfuric acid resistance. They also show a different effect of mortars exposed to sulphate introduced in different forms $\left(5 \% \mathrm{Na}_{2} \mathrm{SO}_{4}\right.$ and $5 \% \mathrm{MgSO}_{4}$ ), with $\mathrm{Na}_{2} \mathrm{SO}_{4}$ causing higher expansion and a more detrimental effect on the mechanical resistance. This seems to be the case in an initial phase [3] but with time material develop expansion and cracking, with the consequent effect on strength. According to Chang et al. [14] limestone reduces acid concentration near the surface of the material and the rate of degradation of concrete subjected to acid attack, however mechanisms of degradation is not yet fully understood.

In the present study we aimed to study the effect of the mineralogical composition in mortar properties by replacing cement by limestone samples collected in different areas of Mozambique (Magude, Massinga and Salmanga). In the production of mortars we used two cement types (Portland cement $32.5 \mathrm{~N}$ and Portland cement $42.5 \mathrm{~N}$ ) in order to compare the effect of the two cement types on properties of mortars.

\section{Materials and Methods}

After collection, samples were crushed, milled, and sieved through a $150 \mu \mathrm{m}$ and dried before preparation of samples for the technological tests. Coarse aggregates, obtained after crushing, were used to test attack by sodium sulphate and potential reactivity of the limestone samples, based on the norm ASTM C 289-1971 [15]. The fine samples where then submitted to a chemical and mineralogical composition, by XRF and XRD respectively, at XRD Analytical and Consulting CC in Pretoria, South Africa.

For preparation of concrete samples for the technological tests (according to the norms ASTM 91977; NM NP EN 197-1:2000 and NBR 9778 (1987)) [16]-[18], cement was partially replaced by amounts of the different limestone powders in the amounts shown in Table 1. 
Table 1. Composition of samples used in technological tests.

\begin{tabular}{cccccc}
\hline \multirow{2}{*}{ Sample } & Amountofcement $(\mathrm{g})$ & \multicolumn{2}{c}{ Amountoflimestone } & Sand $(\mathrm{g})$ & Water $(\mathrm{mL})$ \\
\cline { 3 - 4 } Reference & 450 & $(\%)$ & 0 & \\
F10 & 405 & 10 & 45 & & \\
F15 & 382.5 & 15 & 67.5 & 1350 & 225 \\
F20 & 360 & 20 & 90 & & \\
F25 & 337.5 & 25 & 112.5 & \\
F30 & 315 & 30 & 135 & \\
\hline
\end{tabular}

Samples prepared using the six limestone samples tested in this study (labelled MG1, MG2, SL1, SL2, MS1 and MS2) were then prepared by weighing/measuring the respective amounts of cement, limestone, sand and water, according to the proportions given in Table 1. These samples were prepared with two types of Portland cement namely the $32.5 \mathrm{~N}$ and the $42.5 \mathrm{~N}$ cement.

After weighing the right amount of each component, these were inserted in a mechanical mixer where they were thoroughly mixed, starting with a low velocity (140 \pm 5 r.p.m.) which was increased after one minute to a mixing velocity of $285 \pm 10$ r.p.m.

Prepared mass was then poured into prismatic moulds with $160 \times 40 \times 40 \mathrm{~mm}^{3}$, compacted and maintained on a conditioning chamber for 24 hours, before demoulding (see norm NM NP EN 197-1:2000) [17]. After demoulding, specimens were submitting to curing in water tanks, until curing age was reached, and then submitted to the mechanical tests (flexural strength, compressive strength and water absorption test).

Results of the flexural and compressive strength of the samples with limestone were statistically compared against conventional mortars to verify existence or not of significant differences. These results were then combined with results of the attack by sodium sulphate solution and potential reactivity to decide about applicability of the different compositions.

\section{Results and Discussion}

In this study we used 6 limestone samples collected in Magude (MG1 and MG2), Massinga (MS1 and MS2) and Salamanga (SL1 and SL2). The Salamanga samples are presently used for cement production by Cimentos de Moçambique, the main cement company in Mozambique, while the samples from Massinga are used in concrete production and the Magude samples have been used for paving works. Table 2 shows the chemical composition of the samples while Table 3 presents the results of the semi-quantitative mineralogical composition. Massinga and Salamanga samples show predominantly calcite while the Magude samples present a high amount of dolomite and quartz in its composition.

Results of the effect of the partial replacement of cement by limestone in concrete masses on the mechanical properties of the mortars are presented in Table 4 and Table 5 for the samples prepared with the $32.5 \mathrm{~N}$ and the 42.4N cement respectively.

For a better comparison, these results are graphically presented in Figures 1-6. The Massinga samples (MS1 and MS2), with the higher calcite contents show the best performance, particularly at 10 and $20 \%$ replacement.

Results of the attack by the sodium sulphate solution for the Massinga samples (MS1 and MS2) showed values of $8.3 \%$ and $10.97 \%$ respectively, values below the maximum limit allowed according to the norm ASTM C88 (1976). Magude (MG1 and MG2) and Salamanga (SL1 and SL2) samples showed results above the maximum limit. Results of the potential reactivity against alkalis gave for the Massinga samples good results, thus supporting its potential applicability as aggregate in concrete masses. Massinga samples were the only ones tested for potential reactivity, based on the bad results of the sulphate attack for Magude and Salamanga samples.

Results of the flexural strength show, in general, lower values for the $32.5 \mathrm{~N}$ cement and higher values for the $42.5 \mathrm{~N}$ cement. Results with the $32.5 \mathrm{~N}$ cement are more uniform, while the results obtained with the $42.5 \mathrm{~N}$ cement are higher for the Massinga samples. 
Table 2. Chemical composition of studied samples.

\begin{tabular}{|c|c|c|c|c|c|c|c|c|}
\hline \multirow{3}{*}{ Component } & \multicolumn{8}{|c|}{ Contents in \% } \\
\hline & \multicolumn{6}{|c|}{ Limestone samples } & \multicolumn{2}{|c|}{ Cement } \\
\hline & MG1 & MG2 & SL1 & SL2 & MS1 & MS2 & $32.5 \mathrm{~N}$ & $42.5 \mathrm{~N}$ \\
\hline $\mathrm{CaO}$ & 28.99 & 25.97 & 49.47 & 48.48 & 54.68 & 54.84 & 61.19 & 57.76 \\
\hline $\mathrm{SiO}_{2}$ & 26.79 & 22.54 & 5.00 & 5.61 & 1.98 & 2.85 & 13.90 & 19.59 \\
\hline $\mathrm{Al}_{2} \mathrm{O}_{3}$ & 5.33 & 4.21 & 1.14 & 1.05 & 0.70 & 1.02 & 2.80 & 6,91 \\
\hline $\mathrm{Fe}_{2} \mathrm{O}_{3}$ & 2.19 & 2.00 & 0.77 & 3.65 & 0.35 & 0.55 & 3.10 & 2.67 \\
\hline $\mathrm{MgO}$ & 4.49 & 11.47 & 0.63 & 0.67 & 0.29 & 0.28 & 0.93 & 1.84 \\
\hline $\mathrm{SO}_{3}$ & 0.04 & 0.14 & 0.04 & 0.02 & $<0.01$ & 0.01 & 3.28 & 4.30 \\
\hline $\mathrm{Na}_{2} \mathrm{O}$ & 0.36 & 0.29 & 0.18 & 0.01 & $<0.01$ & $<0.01$ & 0.02 & 0.03 \\
\hline $\mathrm{K}_{2} \mathrm{O}$ & 0.83 & 0.53 & 0.40 & 0.56 & 0.18 & 0.18 & 0.67 & 0.59 \\
\hline LoI & 28.75 & 32.99 & 40.29 & 39.27 & 41.98 & 41.65 & 12.06 & 5.27 \\
\hline
\end{tabular}

Table 3. Mineralogical composition of the samples.

\begin{tabular}{|c|c|c|c|c|c|c|}
\hline \multirow{2}{*}{ Phase } & \multicolumn{6}{|c|}{ Contents in \% } \\
\hline & MG1 & MG2 & SL1 & SL2 & MS1 & MS2 \\
\hline Calcite & 33.00 & 3.86 & 95.71 & 94.58 & 98.24 & 98.70 \\
\hline Montmorilonite & 1.74 & 0.31 & - & - & - & - \\
\hline Quartz & 11.82 & 8.95 & 4.29 & 5.42 & 1.16 & 1.30 \\
\hline Dolomite & 43.60 & 80.06 & - & - & - & - \\
\hline
\end{tabular}

Table 4. Average results of flexural strength, compressive strength and water absorption after 28 days (samples prepared with the $32.5 \mathrm{~N}$ cement).

\begin{tabular}{|c|c|c|c|c|c|c|c|c|}
\hline \multirow{2}{*}{ Property } & \multirow{2}{*}{$\begin{array}{c}\text { Content of } \\
\text { Limestone (\%) }\end{array}$} & \multicolumn{7}{|c|}{ Samples } \\
\hline & & Reference & MG1 & MG2 & SL1 & SL2 & MS1 & MS2 \\
\hline \multirow{4}{*}{$\begin{array}{l}\text { Flexuralstrength } \\
\text { (MPa) }\end{array}$} & 10 & 6.37 & 5.64 & 6.23 & 6.62 & 6.64 & 6.47 & 6.66 \\
\hline & 20 & 6.37 & 5.50 & 5.80 & 5.50 & 6.02 & 5.57 & 6.07 \\
\hline & 25 & 6.37 & 4.95 & 5.31 & 5.15 & 5.76 & 5.20 & 5.83 \\
\hline & 30 & 6.37 & 4.45 & 4.35 & 4.81 & 4.93 & 4.85 & 5.22 \\
\hline \multirow{4}{*}{$\begin{array}{c}\text { Compressivestren } \\
\text { gth (MPa) }\end{array}$} & 10 & 32.73 & 32.54 & 32.76 & 32.73 & 32.79 & 32.80 & 33.46 \\
\hline & 20 & 32.73 & 31.90 & 32.48 & 32.48 & 32.50 & 32.58 & 32.56 \\
\hline & 25 & 32.73 & 31.38 & 31.94 & 31.58 & 31.98 & 32.10 & 32.42 \\
\hline & 30 & 32.73 & 26.78 & 30.80 & 30.80 & 31.32 & 31.20 & 31.47 \\
\hline \multirow{4}{*}{$\begin{array}{l}\text { Waterabsorption } \\
\text { (\%) }\end{array}$} & 10 & 3.44 & 3.73 & 3.52 & 3.44 & 4.02 & 5.02 & 5.27 \\
\hline & 20 & 3.44 & 4.00 & 3.62 & 4.03 & 4.17 & 5.27 & 5.29 \\
\hline & 25 & 3.44 & 4.04 & 3.87 & 4.10 & 4.22 & 5.89 & 5.71 \\
\hline & 30 & 3.44 & 4.43 & 4.16 & 4.23 & 4.55 & 5.99 & 5.90 \\
\hline
\end{tabular}


Table 5. Average results of flexural strength, compressive strength and water absorption after 28 days (samples prepared with the $42.4 \mathrm{~N}$ cement).

\begin{tabular}{|c|c|c|c|c|c|c|c|c|}
\hline \multirow{2}{*}{ Property } & \multirow{2}{*}{$\begin{array}{c}\text { Content of } \\
\text { Limestone (\%) }\end{array}$} & \multicolumn{7}{|c|}{ Samples } \\
\hline & & Reference & MG1 & MG2 & SL1 & SL2 & MS1 & MS2 \\
\hline \multirow{5}{*}{$\begin{array}{l}\text { Flexural strength } \\
\text { (MPa) }\end{array}$} & 10 & 7.98 & 9.64 & 10.49 & 9.83 & 10.57 & 12.18 & 12.47 \\
\hline & 15 & 7.98 & 8.61 & 10.90 & 9.22 & 10.20 & 11.51 & 11.70 \\
\hline & 20 & 7.98 & 9.31 & 9.35 & 9.65 & 9.70 & 11.40 & 11.45 \\
\hline & 25 & 7.98 & 8.40 & 8.86 & 9.13 & 9.17 & 11.20 & 11.28 \\
\hline & 10 & 39.00 & 30.18 & 33.15 & 35.79 & 38.55 & 36.97 & 43.90 \\
\hline \multirow{3}{*}{$\begin{array}{c}\text { Compressive } \\
\text { strength (MPa) }\end{array}$} & 15 & 39.00 & 26.88 & 32.57 & 32.31 & 35.28 & 33.46 & 42.73 \\
\hline & 20 & 39.00 & 24.30 & 30.78 & 29.91 & 31.73 & 34.63 & 40.06 \\
\hline & 25 & 39.00 & 22.38 & 24.99 & 26.13 & 26.20 & 34.63 & 39.49 \\
\hline \multirow{4}{*}{$\begin{array}{l}\text { Water absorption } \\
\text { (\%) }\end{array}$} & 10 & 3.53 & 5.17 & 3.52 & 3.44 & 4.02 & 5.02 & 5.27 \\
\hline & 15 & 3.53 & 5.13 & 3.62 & 4.03 & 4.17 & 5.27 & 5.29 \\
\hline & 20 & 3.53 & 5.62 & 3.87 & 4.10 & 4.22 & 5.89 & 5.71 \\
\hline & 25 & 3.53 & 5.61 & 4.16 & 4.23 & 4.55 & 5.99 & 5.90 \\
\hline
\end{tabular}

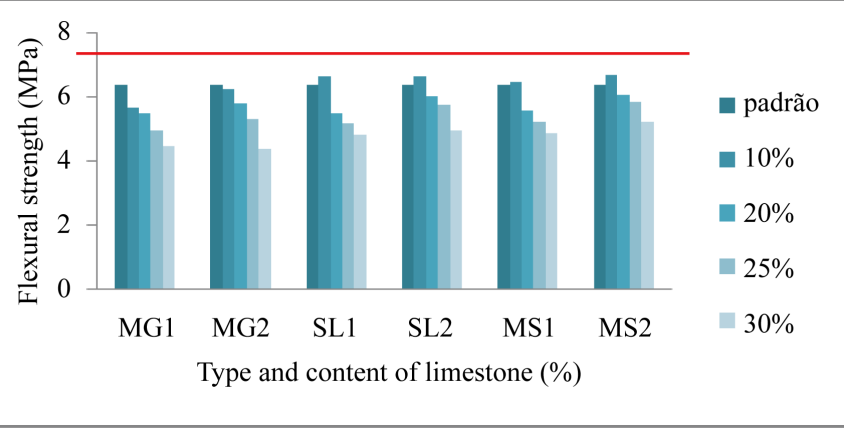

Figure 1. Flexural strength after 28 days curing age (specimens prepared with the $32.5 \mathrm{~N}$ cement).

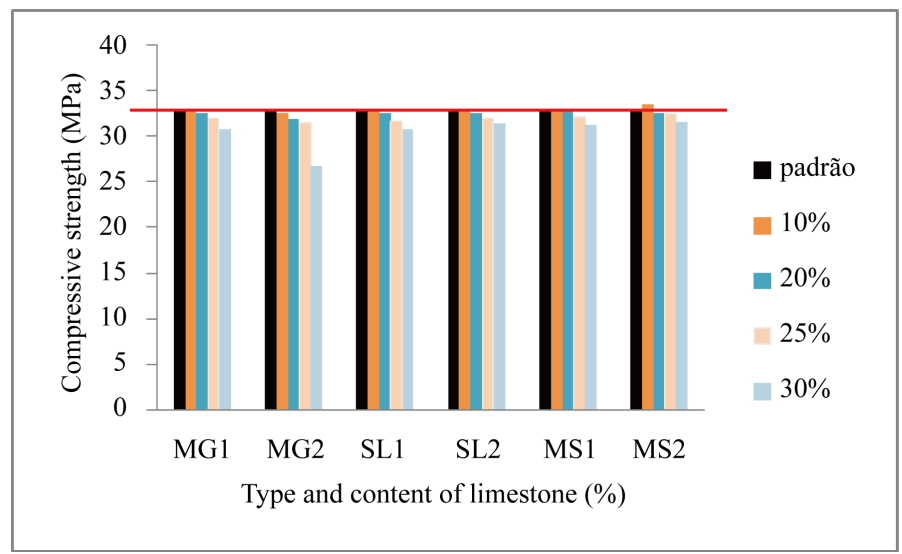

Figure 2. Compressive strength after 28 days curing age (specimens prepared with the $32.5 \mathrm{~N}$ cement). 


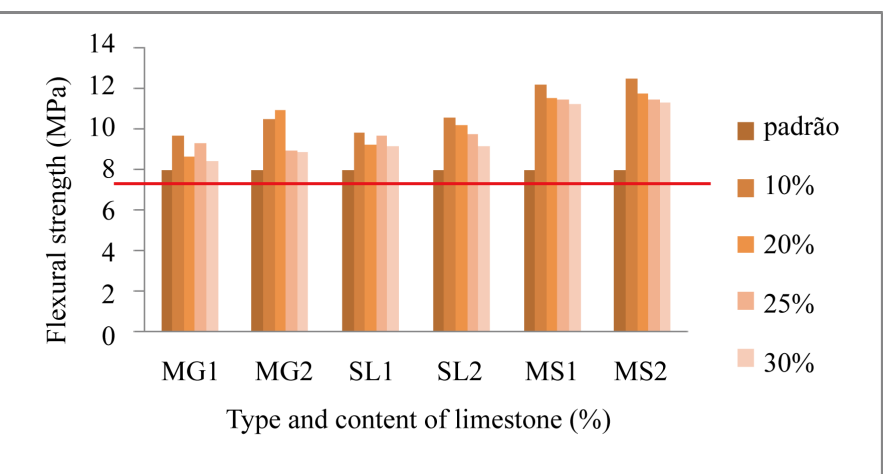

Figure 3. Flexural strength after 28 days curing age (specimens prepared with the $42.5 \mathrm{~N}$ cement).

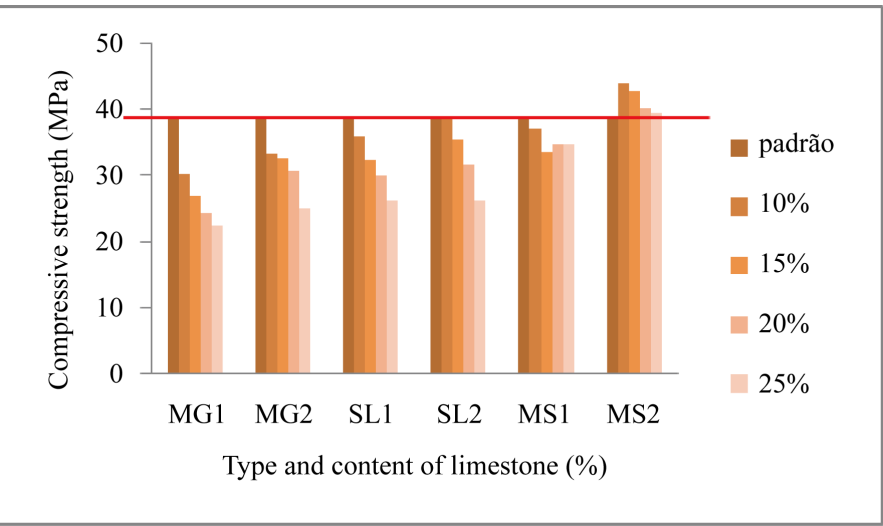

Figure 4. Compressive strength after 28 days curing age (specimens prepared with the $42.5 \mathrm{~N}$ cement).

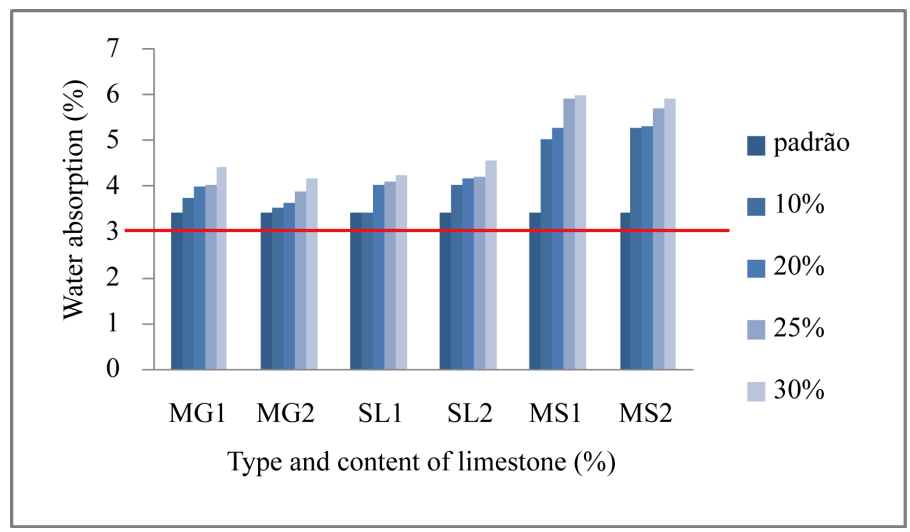

Figure 5. Water absorption after 28 days curing age (specimens prepared with the $32.5 \mathrm{~N}$ cement).

Results of the compressive strength, for the $32.5 \mathrm{~N}$ cement, show a more uniform behaviour, particularly for the Salamanga (SL1 and SL2) and Massinga (MS1 and MS2) samples, even for additions of limestone up to 25\% $30 \%$. Values are slightly lower when compared with the reference material. Values obtained with the $42.5 \mathrm{~N}$ cement with the Magude (MG1 and MG2) and Salamanga (SL1 and SL2) samples are significantly lower than the ones obtained with the reference material. The Massinga samples show the best results, particularly the MS2 samples, which show results of the compressive strength higher that the values obtained with the reference material for all contents of limestone (10, 15, 20 and 25\%), with an increase of the compressive strength of 10\% 


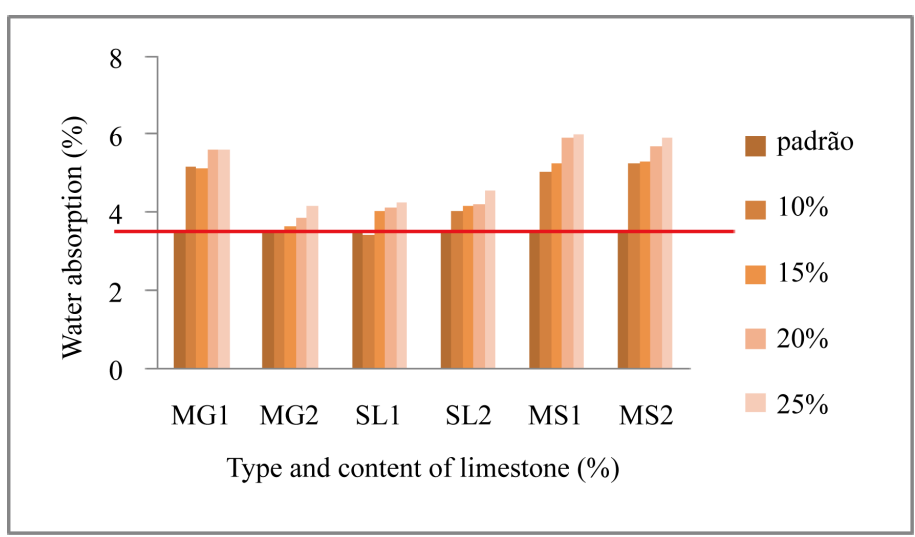

Figure 6. Water absorption after 28 days curing age (specimens prepared with the $42.5 \mathrm{~N}$ cement).

- $12 \%$ for additions of limestone of 10 to $15 \%$.

The water absorption experiments gave values higher than the values of the reference composition, with the samples MG2 and SL1 giving results with the lowest deviations, while samples MS1 and MS2, the samples with the best compressive and flexural strength, show the highest values of the water absorption (Figure 5 and Figure 6).

In general, additions of 10 to $25 \%$ gave, for the $32.5 \mathrm{~N}$ cement, good results of the compressive strength for all limestone samples, while for the $42.5 \mathrm{~N}$ only the MS2 sample performed well. Effect of the limestone additions on the flexural strength show a beneficial effect for all samples and at all compositions studied (10 to 30\% limestone addition), when using the $42.5 \mathrm{~N}$ cement, while for the $32.5 \mathrm{~N}$ cement only additions of $10 \%$ limestone gave values of the flexural strength higher than the ones obtained with the reference material, with the exception of the Magude samples (MG1 and MG2).

Results obtained with the $42.5 \mathrm{~N}$ cement for the Massinga samples are more similar with the results obtained by Knop et al. [10], Bizzozero and Scrivener [11] and Menéndez et al. [5], authors that used a 42.5N cement type. The decrease of the compressive strength in the entire interval, reported by Meddah et al. [1], contrary to the results of this study and the results obtained by Knop et al. [10], Bizzozero and Scrivener [11] and Menéndez et al. [5], may be explained by the fact that Meddah et al. [1] worked with limestone contents higher than $15 \%$, highest beneficial value reported by the other authors.

Calcite limestone samples show, in general, better results, when compared to the dolomitic ones, but the effect of calcite limestone cannot be assessed based only on the mineralogical composition, since Salamanga and Massinga limestone samples show nearly similar calcite contents with 95.71 and $94.58 \%$ calcite on Salamanga samples and 98.24 and $98.70 \%$ on Massinga samples (see Table 2). CaO content goes from nearly $49 \%$ in Salamanga samples to $54 \%$ in the Massinga samples (see Table 1). The expected improvement of the compressive strength achieved by replacement of cement by dolomite limestone reported by Mikhailova et al. [19] was contrary to the results obtained in this study.

Statistical treatment of the results of the flexural and the compressive strength, aimed to test eventual differences among the results, showed for the samples prepared with the $32.5 \mathrm{~N}$ cement good results, except for the MG1 limestone samples. No significant differences were observed for the compressive strength results of the samples with $10 \%$ limestone addition, in comparison with the reference concrete. The flexural strength results for the $10 \%$ replacement were all statistical different but results obtained are higher than the ones obtained for the reference concrete mass. All other results (flexural and compressive strength) obtained with the samples with more than $10 \%$ were different and lower than the conventional concrete sample.

Statistical treatment of the results (flexural and compressive strength) of the specimens prepared with the 42.4N cement were all significantly different from the ones obtained with the reference concrete, but fortunately flexural strength results of the samples prepared with all limestone samples (MG1, MG2, SL1, SL2, MS1 and MS2) for all compositions (10, 15, 20 and 25\% limestone) are higher than flexural strength of the reference sample. On the other side, comparison of the compressive strength gave good results only for the MS2 limestone: Although statistical different, MS2 gave for all compositions (10, 15, 20 and 25\% limestone) values of the com- 
pressive strength above the values obtained for the reference material, thus confirming its potential to replace cement in the above mentioned contents.

\section{Conclusions}

Results presented show a beneficial effect on the mechanical properties of mortars were cement has been partially replaced by limestone, particularly when using calcite limestones. The Massinga samples with reference MS2 showed the best results in the mechanical properties of mortars as well as in the potential reactivity against alkalis.

Although results presented bring evidence of the beneficial effect of limestone additions, in general, at contents not higher than $15 \%$ limestone, further research is needed to better clarify the effect of other variables, like e.g. the water to cement ratio. Since some properties change on a long-term, some properties of the materials (e.g., the decrease of the compressive strength in high sulphate environments reported by Pipilikaki et al. [3]) must be monitored over the 28 days curing age normally used as reference curing age.

\section{Acknowledgements}

The authors wish to acknowledge the financial support from SIDA, from the Swedish Government.

\section{References}

[1] Meddah, M.S., Lmbachiya, M.C. and Dhir, R.K. (2014) Potential Use of Binary and Composite Limestone Cements in Concrete Production. Construction and Building Materials, 58, 193-205. http://dx.doi.org/10.1016/j.conbuildmat.2013.12.012

[2] Menadi, B., Kenai, S., Khatib, J. and Aït-Mokhtar, A. (2009) Strength and Durability of Concrete Incorporating Crushed Limestone sand. Construction and Building Materials, 23, 625-633. http://dx.doi.org/10.1016/j.conbuildmat.2008.02.005

[3] Pipilikaki, P., Katsioti, M. and Gallias, J.L. (2009) Performance of Limestone Cement Mortars in a High Sulfates Environment. Construction and Building Materials, 23, 1042-1049. http://dx.doi.org/10.1016/j.conbuildmat.2008.05.001

[4] Torkaman, J., Ashori, A. and Momtazi, A.S. (2014) Using wood Fiber Waste, Rice Husk and Limestone Powder Waste as Cement Replacement Materials for Lightweight Concrete Blocks. Construction and Building Materials, 50, 432436. http://dx.doi.org/10.1016/j.conbuildmat.2013.09.044

[5] Menéndez, G., Bonavetti, V. and Irassar, E.F. (2003) Strength Development of Ternary Blended Cement with Limestone Filler and Blast-Furnace Slag. Construction and Building Materials, 25, 61-67. http://dx.doi.org/10.1016/s0958-9465(01)00056-7

[6] Courard, L. and Michel, F. (2014) Limestone Fillers Cement Based Composites: Effects of Blast Furnace Slags on Fresh and Hardened Properties. Construction and Building Materials, 51, 439-445. http://dx.doi.org/10.1016/j.conbuildmat.2013.10.076

[7] Sua-Iam, G. and Makul, N. (2013) Use of Increasing Amounts of Bagasse Ash Waste to Produce Self-Compacting Concrete by Adding Limestone Powder Waste. Journal of Cleaner Production, 57, 308-319. http://dx.doi.org/10.1016/j.jclepro.2013.06.009

[8] Sua-Iam, G. and Makul, N. (2013) Utilization of Limestone Powder to Improve the Properties of Self-Compacting Concrete Incorporating High Volumes of Untreated Rice Husk Ash as Fine Aggregate. Construction and Building Materials, 38, 455-464. http://dx.doi.org/10.1016/j.conbuildmat.2012.08.016

[9] Celik, K., Jackson, M.D., Mancio, M., Meral, C., Emwas, A.-H., Mehta, P.K. and Monteiro, P.J.M. (2014) HighVolume Natural Volcanic Pozzolan and Limestone Powder as Partial Replacements for Portland Cement in SelfCompacting and Sustainable Concrete. Cement \& Concrete Composites, 45, 136-147. http://dx.doi.org/10.1016/j.cemconcomp.2013.09.003

[10] Knop, Y., Peled, A. and Cohen, R. (2014) Influences of Limestone Particle Size Distributions and Contents on Blended Cement Properties. Construction and Building Materials, 71, 26-34. http://dx.doi.org/10.1016/j.conbuildmat.2014.08.004

[11] Bizzozero, J. and Scrivener, K.L. (2015) Limestone Reaction in Calcium Aluminate Cement-Calcium. Cement and Concrete Research, 76, 159-169. http://dx.doi.org/10.1016/j.cemconres.2015.05.019

[12] Lollini, F., Redaelli, E. and Bertolini, L. (2014) Effects of Portland Cement Replacement with Limestone on the Properties of Hardened Concrete. Cement \& Concrete Composites, 46, 32-40. 
http://dx.doi.org/10.1016/j.cemconcomp.2013.10.016

[13] Ghrici, M., Kenai, S. and Said-Mansour, M. (2007) Mechanical Properties and Durability of Mortar and Concrete Containing Natural Pozzolana and Limestone Blended Cements. Cement \& Concrete Composites, 29, 542-549. http://dx.doi.org/10.1016/j.cemconcomp.2007.04.009

[14] Chang, Z.-T., Song, X.-J., Munn, R. and Marosszeky, M. (2005) Using Limestone Aggregates and Different Cements for Enhancing Resistance of Concrete to Sulphuric Acid Attack. Cement and Concrete Research, 35, 1486-1494. http://dx.doi.org/10.1016/j.cemconres.2005.03.006

[15] (1971) ASTM C 289-1971: Reapproved 1976.

[16] (1977) ASTM, Concrete and Mineral Aggregates. Part 14, American Society for Testing and Materials, Philadelhia.

[17] (2000) NM NP EN 197-1, Métodos de ensaios de cimentos. Parte 1: Determinação das resistências mecânicas.

[18] (1987) NBR 9778, Argamassa e concreto endurecido—Determinação da absorção de água por imersão—Índice de vazios e massa específica.

[19] Mikhailova, O., Yakovlev, G., Maeva, I. and Senkov, S. (2013) Effect of Dolomite Limestone Powder on the Compressive Strength of Concrete. Procedia Engineering, 57, 775-780. http://dx.doi.org/10.1016/j.proeng.2013.04.098 